\title{
Long-term exposure to near-future ocean acidification does not affect the expression of neurogenesis- and synaptic transmission-related genes in the olfactory bulb of European sea bass (Dicentrarchus labrax)
}

\author{
Mazurais David ${ }^{1,}{ }^{*}$, Servili Arianna ${ }^{1}$, Le Bayon Nicolas ${ }^{1}$, Gislard Sebastien ${ }^{1}$, Madec Lauriane ${ }^{1}$, \\ Zambonino-Infante Jose-Luis ${ }^{1}$
}

${ }^{1}$ IFREMER, Univ Brest, CNRS, IRD, LEMAR, 29280, Brest, Plouzané, France

* Corresponding author : David Mazurais, email address : $\underline{\text { dmazurai@ifremer.fr }}$

\begin{abstract}
:
The decrease in ocean $\mathrm{pH}$ that results from the increased concentration of dissolved carbon dioxide (CO2) is likely to influence many physiological functions in organisms. It has been shown in different fish species that ocean acidification (OA) mainly affects sensory systems, including olfaction. Impairment of olfactory function may be due to a dysfunction of the GABAergic system and to an alteration of neuronal plasticity in the whole brain and particularly in olfactory bulbs. Recent studies revealed that OA-driven effects on sensory systems are partly mediated by the regulation of the expression of genes involved in neurotransmission and neuronal development. However, these studies were performed in fish exposed to acidified waters for short periods, of only a few days. In the present paper, we investigated whether such effects could be observed in adult (4-years old) European sea bass (Dicentrarchus labrax) exposed to two hypercapnic and acidified conditions $(\mathrm{PCO} 2 \approx 980 \mu \mathrm{atm} ; \mathrm{pH}$ total $=7.7$ and $\mathrm{PCO} 2 \approx 1520 \mu \mathrm{atm}$; $\mathrm{pH}$ total $=7.5$ ) from the larval stage. In a first approach, we analyzed by qPCR the expression of five genes involved in neurogenesis (DCX) or expressed in GABAergic (Gabra3), glutamatergic (Gria1) or dopaminergic (TH and DDC) neurons in the olfactory bulbs. The tested experimental conditions did not change the expression of any of the five genes. This result would indicate that a potential disruption of the olfactory function of sea bass exposed for a long term to near-future OA, either occurs at a level other than the transcriptional one or involves other actors of the sensory function.
\end{abstract}




\section{Introduction}

The predicted increase in atmospheric $\mathrm{PCO}_{2}$ level which may reach 420-936 ppm by the end of the century will cause a concurrent ocean acidification $(\mathrm{OA}$ : elevated $\mathrm{H}+$, reduced $\mathrm{pH})$ up to $0.42 \mathrm{pH}$ units (Field 2014). Several studies during last decade examined the potential consequences of marine organisms' exposure to OA, including fish species (Doney et al. 2009; Stillman and Paganini 2015; Wang et al. 2018). In fish, OA has been shown to disrupt cognitive function and to induce behavioral disorders (Chivers et al. 2014; Domenici et al. 2012; Ferrari et al. 2012; Jutfelt et al. 2013; Nilsson et al. 2012) particularly due to alteration of sensory function such as olfaction (Dixson et al. 2015; Dixson et al. 2010; Munday et al. 2009; Rong et al. 2018; Rossi et al. 2016), vision (Chung et al. 2014; Forsgren et al. 2013) and hearing (Rossi et al. 2016). Changes in brain neurotransmitter function and especially in the functioning of the gamma-Aminobutyric acid (GABA) receptor have been argued to explain these effects (Chivers et al. 2014; Nilsson et al. 2012; Regan et al. 2016). In addition to modifying the neuronal $\mathrm{Cl}^{-}$and $\mathrm{HCO}_{3}{ }^{-}$gradients that are important for the GABAA receptor function, OA was shown to up-regulate the mRNA expression of $\alpha$ family subunits $(\alpha 1, \alpha 3, \alpha 4$ and $\alpha 6 b)$ of the GABAA receptor in brains of three-spined stickleback (Gasterosteus aculeatus) (Lai et al. 2017b). Interestingly, recent data obtained in two teleost species [European sea bass (Dicentrarchus labrax) and coho salmon (Oncorhynchus kisutch)] indicated that $\mathrm{OA}$ associated to near future elevated $\mathrm{CO}_{2}$ induces significant changes in gene expression involved in neurotransmission signal. Among these genes, it can be found glutamate (glutamate receptor and transporters) and dopamine/serotonin [aromatic-L-aminoacid decarboxylase (DDC)] signaling related factors in the olfactory bulbs (Porteus et al. 2018; Williams et al. 2019).

In fish, as in other vertebrates, the olfactory bulbs are brain structures that first receive information by olfactory sensory neuron inputs from the olfactory epithelium (Kermen et al. 
2013). The olfactory bulbs are composed of different layers of morphologically and functionally distinct neurons that communicate with each other via synapses, which contribute to the processing of olfactory information. Glutamate, dopamine and GABA are the main neurotransmitters expressed in cells localized in the olfactory bulbs (Edwards and Michel 2002; Kermen et al. 2013). Glutamate is the primary excitatory neurotransmitter for all olfactory sensory neurons in the zebrafish (Danio rerio) olfactory bulb (Edwards and Michel 2002). Dopamine, that has been shown to suppress the synaptic transmissions from mitral to granule cells in the goldfish (Carassius auratus) olfactory bulb, is considered to play an important role in the negative regulation of olfactory responsiveness (Kawai et al. 2012). Regarding GABAergic neurons, that are located in the internal cellular layer of the olfactory bulb in zebrafish, they have been shown to play a critical role in the synchronization of odordependent neuronal signals and the regulation of olfactory bulb output activity (Horzmann and Freeman 2016; Kermen et al. 2013; Tabor et al. 2008).

Additionally to molecular actors involved in neurotransmission, other genes related to brain plasticity and neurogenesis [e.g. Doublecortin $(D C X)$ ] have also been shown to be regulated by OA (Lai et al. 2017a). Such a neurogenetic effect is characteristic to fish species which, unlike mammals, have a high potential to produce new neurons in the adult central nervous system (Zupanc 2001). Interestingly, in the European sea bass juveniles, genes involved in synaptic plasticity and neuronal excitability were shown to be regulated in the olfactory bulbs after exposure to near future $\mathrm{pH}$ (Porteus et al. 2018).

Information gathered on the regulatory mechanisms involved in fish OA response was obtained after relatively short exposure times (from 2 days to 40 days) (Bignami et al. 2014; Dixson et al. 2010; Nilsson et al. 2012; Porteus et al. 2018; Williams et al. 2019).To our knowledge, very few studies have looked at the regulations involved in fish exposed to OA for longer periods (Sundin et al. 2019). Yet, this type of response is ecologically relevant in 
order to evaluate the resilience capacity of fish when facing global change related effects such as OA. Recently, studies performed in juvenile spiny chromis damselfish (Acanthochromis polyacanthus) showed that long-term acclimation to near-future ocean acidification did not induce any acid-base disruption of energetics (Sundin et al. 2019). This result contrasted with several short-term studies considering that alteration of GABAA receptor function may be a mechanistic explanation for the reported hyperactivity and other behavioural impairments of fishes under elevated $\mathrm{CO}_{2}$.

In this study, we aimed to examine whether molecular actors differentially expressed by a short exposure to acidification, could also be found regulated in the olfactory bulb of sea bass exposed for 4 years to a near future OA. For this purpose, we quantified mRNA expression levels of genes involved in neurogenesis (DCX) and in glutamatergic (glutamate ionotropic receptor), GABA ergic (gamma-aminobutyric acid type A receptor alpha3 subunit) and dopaminergic (tyrosine hydroxylase and DDC) neurons of the olfactory bulbs. 


\section{Materials and methods}

\section{Animal and experimental conditions}

Adult European sea bass used in this study were from the same experimental population used in a previous study that examined the impact of OA during larval development (Crespel et al. 2017). Sea bass were maintained from larval to adult stage (four years post-hatching) in three $\mathrm{pH} / \mathrm{PCO}_{2}$ conditions [i.e. $\mathrm{PCO}_{2} \approx 590 \mu$ atm for Control group at $\mathrm{pH}$ total $=7.9 ; \mathrm{PCO}_{2} \approx 980$ $\mu$ atm for low acidity group (LA) at $\mathrm{pH}$ total $=7.7 ; \mathrm{PCO}_{2} \approx 1520 \mu$ atm for high acidity (HA) group at $\mathrm{pH}$ total $=7.5]$. The choice of the experimental conditions were based to the IPCC Representative Concentration Pathway (RCP) 6.0 and IPCC RCP8.5 scenario predicting a $\Delta$ $\mathrm{PCO}_{2}$ of $\approx 500 \mu \mathrm{atm}$ and $\approx 1000 \mu \mathrm{atm}$ by the end of the present century, respectively (Collins 2014). The rearing conditions during larval stage are detailed in the previous paper (Crespel et al. 2017). The sea water was pumped $500 \mathrm{~m}$ from the coastline in the Bay of Brest, from a depth of $20 \mathrm{~m}$ approximately, passed through a $\sim 500 \mu \mathrm{m}$ sand filter, heated (tungsten, Plate Heat Exchanger, Vicarb, Sweden), degassed using a column, filtered using a $2 \mu \mathrm{m}$ membrane and finally UV sterilized (PZ50, 75W, Ocene, France). Larvae were maintained at $19{ }^{\circ} \mathrm{C}$, with oxygen concentration above $90 \%$, salinity at $34 \%$ and the controlled photoperiod was set at 24D during the first week of development and then at 16L:8D until 45dph. Larvae were fed ad libitum with Artemia until 28 dph and then with commercial dry pellets (Néo-start, Le Gouessant Aquaculture, France) until 45 dph. At juvenile stage, fish were maintained at $18^{\circ} \mathrm{C}$, 16L:8D and fed a commercial feed (Neo Grower Extra Marin, Le Gouessant Aquaculture, France). From two years post-hatching, adult fish were reared under natural photoperiod and ambient temperature (between 10 to $19^{\circ} \mathrm{C}$ : natural seasonal differences in the Bay of Brest) and fed a diet that encompasses the specific nutritional requirements of Broodstock (Vitalis

Cal, Skretting, Stavanger, Norway). Apart from $\mathrm{PCO}_{2}$ and associated $\mathrm{pH}$ conditions, fish from 
the three groups experienced identical experimental conditions (water temperature, salinity, oxygenation, food, etc.) throughout their whole lives.

All fish experiments were conducted under approved protocols in strict compliance with the EU Directive 2010/63/EU for animal experiments. The present work conforms to the French legal requirements concerning welfare of experimental animals (APAFIS permit no. 171322018101614401562).

mRNA expression analysis

Total RNA extraction was performed from olfactory bulbs sampled on 40 fish (4 years old; 1 $240 \pm 252 \mathrm{~g}): 14$ individuals from the control group (10 females, 4 males), 13 individuals from the LA group (12 females, 1 male), 13 individuals from the HA group (6 females, 7 males) at post-spawning period. Before sampling, fish were fasted for $24 \mathrm{~h}$. Fish were first lightly anaesthetized $\left(20 \mathrm{mg} \mathrm{L}^{-1}\right)$, and then euthanized with a lethal dose $\left(200 \mathrm{mg} . \mathrm{L}^{-1}\right)$ of Tricaine methane-sulfonate 222 (Pharmaq, Fordingbridge, Hampshire, UK). The fish brain was quickly removed, and then the olfactory bulbs were dissected and stored in RNA Stabilization Reagent (RNAlater, Qiagen, Hilden, Germany) following recommendations from the supplier. Total RNA was extracted using Extract-all reagent (Eurobio, Courtaboeuf, Essonne, France) combined with Nucleospin RNA column that includes one step of DNase treatment (Macherey-Nagel, Düren, Germany) according to the manufacturer's instructions. The concentration, purity and integrity were determined using a ND-1000 NanoDrop ${ }^{\circledR}$ spectrophotometer (Thermo Scientific Inc., Waltham, MA, USA) and by electrophoresis using an Agilent Bioanalyser 2100 (Agilent Technologies Inc., Santa Clara, CA, USA). All samples showed an RNA integrity score (RIN) higher than 8 and thus could be used for 
reverse transcription-quantitative PCR (RT-qPCR) analysis. RNA samples were stored at $-80^{\circ} \mathrm{C}$ until use.

Retrotranscription (RT) of cDNA for all samples was carried out using $500 \mathrm{ng}$ of RNA with an iScript ${ }^{\mathrm{TM}}$ cDNA Synthesis kit (Bio-Rad Laboratories Inc., Hercules, CA, USA) following strictly recommendations from the supplier. cDNA was stored at $-20^{\circ} \mathrm{C}$ until use. Negative RT controls were performed for all samples.

Quantitative real time PCR was performed for the five genes of interest (DCX, Grial, Gabra3, TH, DDC) and two housekeeping genes [elongation factor 1-alpha (ef1 $\alpha)$ and 28S rRNA] using the primers listed in Table 1.

Table 1: Specific primers used for real time amplification.

\begin{tabular}{|c|c|c|c|}
\hline Genes & $\begin{array}{c}\text { Accession } \\
\text { number }\end{array}$ & Forward primer (5'-3') & Reverse primer (5'-3') \\
\hline$D C X$ & MN183104 & ACACACTTGATGGCAAGCAG & TCATCACCCTGCATTCGTTA \\
\hline Grial & MN183103 & GATGCTCTGGTGGGAGTGAT & TTCAAGAAGGACGCCTCTGT \\
\hline Gabra3 & MN183105 & CCGAGAATCAGTTCCTGCTC & TGCGCTTGGTGAAGTAGTTG \\
\hline TH & MN183107 & ATGTCGGAAGCTCAAGGAGA & CTTTTTGGGAACCAGTGGAA \\
\hline$D D C$ & MN183106 & CTGAGAGCAGGGAGATCCAC & CCTGCAAAAGCTCAAAGGTC \\
\hline efla & AJ866727.1 & CTGGAGGGCAGTGAAAAGAT & CATCAAGAGCCTCCAGCAGT \\
\hline $28 S$ rRNA & AH011863.2 & GTCCTTCTGATCGAGGCTCA & CGTGCCGGTATTTAGCCTTA \\
\hline
\end{tabular}

Gene expression was quantified using the CFX96 Touch Real-Time PCR Detection system (Bio-Rad Laboratories Inc.). Standard curves were estimated for each primer pair using serial dilutions (from1/10 to 1/270) of a pool of cDNA. Efficiencies of qPCR for each pair of 
primers ranged from $95 \%$ to $100 \%$ with R2>0.99. Each sample was analysed in triplicate in a final well volume of $15 \mu \mathrm{l}$ containing $5 \mu \mathrm{l}$ cDNA (1/30 dilution) and $10 \mu \mathrm{l}$ of reaction mix, composed of $0.5 \mu \mathrm{l}$ of each primer (10 mmol 1-1), $1.5 \mu \mathrm{l}$ RNase/DNase-free water and $7.5 \mu 1$ $\mathrm{iQ}^{\mathrm{TM}}$ SYBR ${ }^{\circledR}$ Green Supermix (Bio-Rad Laboratories Inc.). Negative RT controls were also analysed to check for potential contamination. The qPCR profiles contained an initial activation step at $95^{\circ} \mathrm{C}$ for $2 \mathrm{~min}$ followed by 40 cycles of $5 \mathrm{~s}$ at $95^{\circ} \mathrm{C}$ and $20 \mathrm{~s}$ at $60^{\circ} \mathrm{C}$. After the amplification phase, a high resolution melting curve was performed to confirm the amplification of a single product in each reaction. For all samples, the corresponding $\mathrm{Cq}$ (quantification cycle) value was determined automatically using the Gene Expression Module of the CFX Manager software (Bio-Rad Laboratories Inc.). The relative quantity of messenger was normalized with the $\Delta \Delta \mathrm{Ct}$ method using ef1 $\alpha$ and $28 \mathrm{~S}$ rRNA as reference genes. These reference genes were used as they did not even show low variation of expression between samples (relative standard deviation $<5 \%$ among samples).

A two-way ANOVA including sex and acidification status as independent factors was used to test significant differences between treatments. For all analyses, variables were checked for normality (Shapiro test) and equality of variances (Levene test). The level of significance was taken at 0.05 . 
Table 2: Statistical analysis of expression data ${ }^{a}$

\begin{tabular}{|c|c|c|c|c|c|c|c|c|c|}
\hline \multirow[t]{3}{*}{ Gene } & \multicolumn{6}{|c|}{ Conditions } & \multicolumn{3}{|c|}{$p$ value } \\
\hline & \multicolumn{2}{|c|}{ Control } & \multicolumn{2}{|l|}{$L A$} & \multicolumn{2}{|c|}{$H A$} & \multirow{2}{*}{ Sex } & \multirow{2}{*}{ Acid. } & \multirow{2}{*}{$\begin{array}{l}\text { Sex * } \\
\text { Acid. }\end{array}$} \\
\hline & $F(10)$ & $M(4)$ & $F(12)$ & $M(1)$ & $F(6)$ & $M(7)$ & & & \\
\hline$D C X$ & $0.62 \pm 0.18$ & $0.52 \pm 0.08$ & $0.66 \pm 0.22$ & 0.66 & $0.60 \pm 0.06$ & $0.67 \pm 0.35$ & $p=0.930$ & $p=0.749$ & $p=0.822$ \\
\hline Grial & $0.75 \pm 0.41$ & $0.52 \pm 0.07$ & $0.70 \pm 0.29$ & 0.76 & $0.62 \pm 0.08$ & $0.68 \pm 0.31$ & $p=0.950$ & $p=0.881$ & $p=0.596$ \\
\hline Gabra3 & $0.66 \pm 0.21$ & $0.55 \pm 0.08$ & $0.94 \pm 0.31$ & 0.61 & $0.62 \pm 0.07$ & $0.69 \pm 0.26$ & $p=0.244$ & $p=0.439$ & $p=0.402$ \\
\hline$T H$ & $0.47 \pm 0.50$ & $0.19 \pm 0.28$ & $0.33 \pm 0.49$ & 0.79 & $0.20 \pm 0.34$ & $0.06 \pm 0.03$ & $p=0.757$ & $p=0.192$ & $p=0.223$ \\
\hline$D D C$ & $0.63 \pm 0.27$ & $0.51 \pm 0.16$ & $0.77 \pm 0.35$ & 0.82 & $0.66 \pm 0.07$ & $0.78 \pm 0.42$ & $p=0.825$ & $p=0.510$ & $p=0.788$ \\
\hline
\end{tabular}

a: Expression levels for each gene were presented as means \pm standard deviation and analyzed using a two-way ANOVA and included sex and acidification status as the independent factors. Numbers in brackets indicate sample sizes. The table shows the p-values for each factor. LA: Low acidification condition; HA: High acidification condition. 


\section{Discussion}

In an attempt to get information about the long term acclimation of fish to OA, the objective of the present study was to determine whether prolonged experimental exposure of European sea bass (i.e. from larval to adult stage) to near future ocean $\mathrm{pH}$ influenced expression of genes that play role in neurogenesis and neurotransmission in the olfactory bulbs. Our results indicate that $D C X$ gene involved in neurogenesis and Grial, Gabra3 and TH and DDC neurotransmitter-related genes involved in glutamatergic, GABAergic and dopaminergic neurons respectively, were not differentially expressed among all tested $\mathrm{pH}$ conditions.

The $\mathrm{PCO}_{2}$ levels associated to OA that we tested (i.e. $\approx 590 \mu$ atm for Control condition at $\mathrm{PH}$ total= 7.9; $\approx 980 \mu \mathrm{atm}$ at $\mathrm{pH} 7.7 ; \approx 1520 \mu \mathrm{atm}$ at $\mathrm{pH} 7.5$ ) were higher than those used in previous studies (Lai et al. 2017a; Porteus et al. 2018). However, the $\Delta$ PCO2 of $\approx 500 \mu$ atm and $\approx 1000 \mu$ atm that we have chosen to simulate OA were similar and based on IPCC RCP6.0 and RCP8.5 scenario (Collins 2014). Therefore we assume that the absence of effect found in the present work was not related to experimental conditions.

The lack of regulation of $D C X$ gene expression contrasts with previous data obtained in stickleback indicating up-regulation of this gene by OA, but is in line with responses observed in cinnamon anemonefish and spiny damselfish (Lai et al. 2017a). Lai et al suggested that interspecies variability in the sensitivity of $D C X$ gene expression to OA may reflect differential physiological plasticity between fish species (Lai et al. 2017a). The absence of $D C X$ gene regulation observed in the present study may not be related to a low molecular plasticity of European sea bass brain structure with respect to acidified condition. Indeed, expression of a hundred genes including actors involved in neurogenesis (i.e. NAV3) were shown to be regulated in the olfactory bulb of European sea bass exposed for 2-7 days to near future $\mathrm{pH}(\mathrm{pH}, 7.82 \pm 0.01 ; 1122 \pm 19 \mu \mathrm{atm})$ (Porteus et al. 2018). Moreover, in European sea 
bass as in teleost fish, brain is characterized by extensive adult neurogenesis providing an excellent model for adult brain plasticity. We assume that the absence of regulation of $D C X$ gene expression in the present study may be related to the long time exposure of fish to acidification conditions and we can only speculate that if $D C X$ gene expression is sensitive to $\mathrm{OA}$ in European sea bass, this is a transient regulation occurring during the first days/weeks of exposure to low $\mathrm{pH}$. A time series analysis of $D C X$ gene expression levels throughout the exposure to acidified environment would constitute a proof of this theory. Moreover, we also can not exclude the possibility that $D C X$ gene expression may be regulated in other parts of the central nervous system since other authors found this gene regulated from whole brain samples (Lai et al. 2017a).

We can also speculate a similar regulation control for neurotransmission related genes Griala, gabra3 and DDC which did not exhibit differential expression in the present study after long term exposure to similar acidification conditions, when they were shown to be regulated during short term exposure to OA in European sea bass or stickleback (Lai et al. 2017b; Porteus et al. 2018). Interestingly, the regulation of these genes was associated with impaired olfaction in fish exposed to OA. The absence of Griala, gabra3 and DDC gene regulation does not necessarily mean that the olfactory system is not impacted by the longterm exposure to OA but if it is, other molecular actors and mechanisms are likely involved.

The alteration of GABA neurotransmitter function has been proposed as the main mechanism explaining the OA induced behavioral impairment in fish (Nilsson et al. 2012). The absence of gabra3 gene regulation suggested that, as proposed in juvenile spiny chromis damselfish, the GABA function was not modified in fish long term exposed to OA (Sundin et al. 2019). However, as suggested by Williams et al (2019), we can not exclude in the present study that other molecular actors (such as gamma-aminobutyric acid type B receptor subunit 2 gene) involved in GABA function may be regulated. Finally, the fact that the expression levels of 
key genes (DDC and $T H$ ) playing an important role in the physiology of dopaminergic neurons (DA) were not found regulated in the present study, suggested that the known DA neurons-induced negative regulation of olfactory responsiveness is not stimulated in European sea bass exposed for a long time to OA (Kawai et al. 2012).

In conclusion, to our knowledge, the present study is the first that addressed the influence of long term exposure of $\mathrm{OA}$ on the expression of genes involved in the processing of olfactory information in a teleost species. In contrast to what has been shown during short exposures to acidified water, long-term exposures do not appear to influence genes involved in the processing of olfactory information. However, this does not necessary suggest a total physiological resilience of European sea bass and particularly that olfaction is not altered by long term exposure to OA. Behavioral experiments and electrophysiological analysis of olfactory sensitivity in the adult European sea bass used in the present study would be necessary to evaluate potential impairment of olfactory function when fish are long term exposed to OA. The present study mainly indicates that mechanisms involved in OA response in the olfactory bulb of European sea bass likely depends on the exposure duration, which could be of great importance from an ecological point of view.

\section{Acknowledgments}

This work was supported by LabexMer (ANR-10-LABX-0019,OASYS project), the Ministry of Ecological and Solidarity Transition and the Foundation for Biodiversity Research (Ocean Acidification Program, PACIO project) and the Deutsche Forschungemeinschaft, PE 1157/81, MA4271/3-1 (the FITNESS project). 


\section{References}

Bignami S, Sponaugle S, Cowen RK (2014) Effects of ocean acidification on the larvae of a high-value pelagic fisheries species, mahi-mahi Coryphaena hippurus Aquat Biol 21:249-260 doi:10.3354/ab00598

Chivers DP et al. (2014) Impaired learning of predators and lower prey survival under elevated CO2: a consequence of neurotransmitter interference Global Change Biol 20:515-522 doi:10.1111/gcb.12291

Chung WS, Marshall NJ, Watson SA, Munday PL, Nilsson GE (2014) Ocean acidification slows retinal function in a damselfish through interference with GABAA receptors J Exp Biol 217:323-326 doi:10.1242/jeb.092478

Collins M, R. Knutti, J. Arblaster, J.-L. Dufresne, T. Fichefet, P. Friedlingstein, X. Gao, W.J. Gutowski, T. Johns, G. Krinner, M. Shongwe, C. Tebaldi, A.J. Weaver and M. Wehner (2014) Long-term Climate Change: Projections, Commitments and Irreversibility Pages 1029 to 1076. In: Intergovernmental Panel on Climate C (ed) Climate Change 2013 - The Physical Science Basis: Working Group I Contribution to the Fifth Assessment Report of the Intergovernmental Panel on Climate Change. Cambridge University Press, Cambridge, pp 1029-1136. doi:DOI: 10.1017/СBO9781107415324.024

Crespel A et al. (2017) The development of contemporary European sea bass larvae (Dicentrarchus labrax) is not affected by projected ocean acidification scenarios Mar Biol 164 doi:ARTN $15510.1007 / \mathrm{s} 00227-017-3178-x$

Dixson DL, Jennings AR, Atema J, Munday PL (2015) Odor tracking in sharks is reduced under future ocean acidification conditions Global Change Biol 21:1454-1462 doi:10.1111/gcb.12678

Dixson DL, Munday PL, Jones GP (2010) Ocean acidification disrupts the innate ability of fish to detect predator olfactory cues Ecol Lett 13:68-75 doi:10.1111/j.1461-0248.2009.01400.x

Domenici P, Allan B, McCormick MI, Munday PL (2012) Elevated carbon dioxide affects behavioural lateralization in a coral reef fish Biol Lett 8:78-81 doi:10.1098/rsbl.2011.0591

Doney SC, Fabry VJ, Feely RA, Kleypas JA (2009) Ocean acidification: the other CO2 problem Ann Rev Mar Sci 1:169-192 doi:10.1146/annurev.marine.010908.163834

Edwards JG, Michel WC (2002) Odor-stimulated glutamatergic neurotransmission in the zebrafish olfactory bulb J Comp Neurol 454:294-309 doi:10.1002/cne.10445

Ferrari MCO et al. (2012) Effects of Ocean Acidification on Learning in Coral Reef Fishes Plos One 7 doi:ARTN e3147810.1371/journal.pone.0031478

Field CB, V.R. Barros, D.J. Dokken, K.J. Mach, M.D. Mastrandrea, T.E. Bilir, M. Chatterjee, K.L. Ebi, Y.O. Estrada, R.C. Genova, B. Girma, E.S. Kissel, A.N. Levy, S. MacCracken, P.R. Mastrandrea, and L.L. White (2014) Contribution of Working Group II to the Fifth Assessment Report of the Intergovernmental Panel on Climate Change. In. Cambridge University Press, Cambridge, United Kingdom and New York, NY, USA, p 1132

Forsgren E, Dupont S, Jutfelt F, Amundsen T (2013) Elevated CO2 affects embryonic development and larval phototaxis in a temperate marine fish Ecol Evol 3:3637-3646 doi:10.1002/ece3.709

Horzmann KA, Freeman JL (2016) Zebrafish Get Connected: Investigating Neurotransmission Targets and Alterations in Chemical Toxicity Toxics 4:19 doi:10.3390/toxics4030019

Jutfelt F, Bresolin de Souza K, Vuylsteke A, Sturve J (2013) Behavioural disturbances in a temperate fish exposed to sustained high-CO2 levels Plos One 8:e65825 doi:10.1371/journal.pone.0065825

Kawai T, Abe H, Oka Y (2012) Dopaminergic neuromodulation of synaptic transmission between mitral and granule cells in the teleost olfactory bulb J Neurophysiol 107:1313-1324

Kermen F, Franco L, Wyatt C, Yaksi E (2013) Neural circuits mediating olfactory-driven behavior in fish vol 7. doi:10.3389/fncir.2013.00062 
Lai F, Fagernes CE, Bernier NJ, Miller GM, Munday PL, Jutfelt F, Nilsson GE (2017a) Responses of neurogenesis and neuroplasticity related genes to elevated $\mathrm{CO} 2$ levels in the brain of three teleost species Biol Letters 13 doi:ARTN 2017024010.1098/rsbl.2017.0240

Lai F, Fagernes CE, Jutfelt F, Nilsson GE (2017b) Expression of genes involved in brain GABAergic neurotransmission in three-spined stickleback exposed to near-future $\mathrm{CO} 2$ (vol 4, pg 1, 2016) Conserv Physiol 5 doi:ARTN cox00410.1093/conphys/cox004

Munday PL, Dixson DL, Donelson JM, Jones GP, Pratchett MS, Devitsina GV, Doving KB (2009) Ocean acidification impairs olfactory discrimination and homing ability of a marine fish Proc Natl Acad Sci U S A 106:1848-1852 doi:10.1073/pnas.0809996106

Nilsson GE, Dixson DL, Domenici P, McCormick MI, Sorensen C, Watson SA, Munday PL (2012) Nearfuture carbon dioxide levels alter fish behaviour by interfering with neurotransmitter function Nat Clim Change 2:201-204 doi:10.1038/Nclimate1352

Porteus CS, Hubbard PC, Webster TMU, van Aerie R, Canario AVM, Santos EM, Wilson RW (2018) Near-future CO2 levels impair the olfactory system of a marine fish Nat Clim Change 8:737-+ doi:10.1038/s41558-018-0224-8

Regan MD et al. (2016) Ambient CO2, fish behaviour and altered GABAergic neurotransmission: exploring the mechanism of $\mathrm{CO} 2$-altered behaviour by taking a hypercapnia dweller down to low CO2 levels Journal of Experimental Biology 219:109-118 doi:10.1242/jeb.131375

Rong JH et al. (2018) Ocean Acidification Impairs Foraging Behavior by Interfering With Olfactory Neural Signal Transduction in Black Sea Bream, Acanthopagrus schlegelii Front Physiol 9 doi:ARTN 159210.3389/fphys.2018.01592

Rossi T, Nagelkerken I, Pistevos JCA, Connell SD (2016) Lost at sea: ocean acidification undermines larval fish orientation via altered hearing and marine soundscape modification Biol Letters 12 doi:ARTN 2015093710.1098/rsbl.2015.0937

Stillman JH, Paganini AW (2015) Biochemical adaptation to ocean acidification J Exp Biol 218:19461955 doi:10.1242/jeb.115584

Sundin J, Amcoff M, Mateos-Gonzalez F, Raby GD, Clark TD (2019) Long-term acclimation to nearfuture ocean acidification has negligible effects on energetic attributes in a juvenile coral reef fish Oecologia 190:689-702 doi:10.1007/s00442-019-04430-z

Tabor R, Yaksi E, Friedrich RW (2008) Multiple functions of GABA A and GABA B receptors during pattern processing in the zebrafish olfactory bulb Eur J Neurosci 28:117-127 doi:10.1111/j.1460-9568.2008.06316.x

Wang M, Jeong CB, Lee YH, Lee JS (2018) Effects of ocean acidification on copepods Aquatic toxicology (Amsterdam, Netherlands) 196:17-24 doi:10.1016/j.aquatox.2018.01.004

Williams CR et al. (2019) Elevated CO2 impairs olfactory-mediated neural and behavioral responses and gene expression in ocean-phase coho salmon (Oncorhynchus kisutch) Global Change Biol 25:963-977 doi:10.1111/gcb.14532

Zupanc GK (2001) Adult neurogenesis and neuronal regeneration in the central nervous system of teleost fish Brain Behav Evol 58:250-275 doi:10.1159/000057569 